\title{
ESP Needs Analysis of Iranian MA Students: A Case Study of the University of Isfahan
}

\author{
Fatemeh Moslemi \\ University of Isfahan, Iran \\ E-mail: Fatememoslemi14@yahoo.com \\ Ahmad Moinzadeh \& Azizollah Dabaghi \\ Department of English Language Teaching, Faculty of Foreign Languages \\ University of Isfahan, Isfahan, Iran \\ E-mail: moin@fgn.ui.ac.ir; dabaghi@fgn.ui.ac.ir
}

Received: January 14, 2011

Accepted: May 16, 2011

Published: December 1, 2011

doi:10.5539/elt.v4n4p121

URL: http://dx.doi.org/10.5539/elt.v4n4p121

\begin{abstract}
The aim of this study was to investigate the foreign language learning needs of Iranian MA students, in particular those who were majoring in biology, psychology, physical training, accounting and west philosophy. A total of 80 students from five MA majors studying at university of Isfahan participated in the study. Additionally, twenty- five subject-specific instructors as well as seven English instructors took part in the study. The study was designed on qualitative and quantitative survey basis using interviews, questionnaires, and texts. In order to investigate participants' point of views, chi-square test was used to analyze the data. The result obtained revealed that majority of the participants were dissatisfied with the current ESP courses for MA students. Most of the participants asked for an urgent need for revision and reconsideration of English instruction in the Iranian educational system as well as universities, stating that Iranian students do not have enough exposure to English language in a way that help them to fulfill their subjective and objective needs at MA level. Giving more weight to English in the MA entrance exam was suggested as one possible solution. It was thought that this would increase the motivation of the students to improve their language proficiency; furthermore, joint teaching of the ESP courses was suggested as another solution to help students meet their English needs at the MA level.
\end{abstract}

Keywords: ESP, Needs analysis, Objective needs, Subjective needs, Joint teaching

\section{Introduction}

English for Specific Purposes (ESP) is a developing branch of English as Foreign Language (EFL) instruction in Iran. As in many countries, teaching EAP has a marginal status in Iranian tertiary education, with no clear guidance from institutions or from the Ministry of Science, Research, and Technology (MSRT). The main aim of EAP classes is to improve technical vocabulary, reading and translation skills and the textbooks seem to represent what the students need to "know" in order pass their exams. In this regard, Iran's universities present English for Specific Purposes (ESP) courses to help students overcome their foreign language problems. However, students sound dissatisfied with the instruction and outcome of these courses. Iranian university students at the undergraduate level of different disciplines have to pass English for Specific Purposes (ESP) course which utilizes a text-centered approach and can be described as examination-centered. In most disciplines, students in particular those who are majoring in biology, psychology, physical training; accounting and west philosophy are required to study their course and related articles in English language. This problem, because of two reasons is not that much conspicuous while they are going through undergraduate level: first, in all the majors at least an ESP course is presented for the students, they pass the course, whether learning English on not. Second, most of the books studied at the undergraduate level are translated into Persian, so it is an enormous help for them as they compare the English references with their translated texts. Although most of the translations are not satisfactory, it paves the way for undergraduate students to comprehend English sentences better.

At the graduate level, the problem gets worse since reference books are in English. Above all, Students majoring in different disciplines are required to write academic articles in English and this basic requirement is even more 
sensed whilst most of the majors do not have any ESP courses.

According to the information gathered through questionnaires, among five majors of biology, psychology, physical training, accounting and west philosophy, only those who are majoring in west philosophy and accounting have to pass an ESP course. Regardless of students' desperate need of English, presenting an ESP course is overlooked in most of the majors at the graduate level and if there is any, the students would not get competent enough to get along with the requirements of writing English articles in professional journals or speaking in seminars. In deed, it has been noticed that the content, methodology ,classroom techniques and activities which are expected to emphasize the development of reading skills actually encourage the students to translate some texts from English to Persian, Moreover translated books available in bazaar are not agreeable; the old ones were better, the new ones are terrible.

The bulk of specific purpose foreign language instruction in Iran which is expected to deal with teaching English for academic purposes (EAP) is of limited scope and seems to have overlooked the principles underlying ESP course design. In fact as Yarmohammadi $(2005$, p.4) points out, "language teaching in Iran doesn't follow any specific purposes, i.e. it can be characterized as language for no specific purposes".

In this regard, various researches have been conducted in Iran, focusing on the ESP needs of university students. Some examples of which are the ESP materials of the university of Azarbayejan, Tabriz (Dudley-Evans, 1976), analyzing discoursal and formal needs of students of Psychology \& sociology (Fakharzadeh, 2000), A reappraisal study of discipline-based EAP program in Iran (Atai, 2000), Iranian EAP program in practice (Atai, 2002a), A genre-based reading comprehension course for the students of dentistry (Atai, 2002b), Teaching English for Specific Purposes: a no man's land area of activity : Investigating ESP courses administered in Iranian Universities (Eslami, 2005) and developing a profile of the ESP needs for Iranian students of medical and midwifery (Mazdayasna, 2008). The underlying assumption of all these studies is that relevance of English course to the students' needs would improve their motivation and thereby make learning better and faster.

By and large, Iranian Master of Arts (MA) students are not qualified enough to write English article or express their views while competing in important educational arenas. Certainly, they are expert in their own field of study but in order to make more progress, they need to develop their English proficiency. Given that language learning is a dynamic process and the role of Iran's educational system can not be neglected throughout twelve years of study at schools, the researcher hypothesized that the problem of English proficiency of MA students might be deep-rooted in Iran's educational system. Therefore, the main aim of conducting this study was to investigate the English language learning needs, wants and desires of MA students of Isfahan university-specifically those majoring in biology, psychology, physical training, accounting and west philosophy-in order to help them overcome their problems. The assessment of learners' needs was performed by considering the views of various stakeholders including students, subject-specific instructors as well as English instructors. Efforts were made to find answers to the following questions:

1. What are the ESP needs of Iranian MA students?

2. Where do the problems of Iranian MA students (regarding English) stem from? What are the possible recommendations to solve these problems?

\section{Method}

\subsection{Design of the study}

This mixed methods study involved first, a small scale interview study with graduate students, English instructors, and subject-specific instructors in the University of Isfahan. The interview data provided input to the design of a fairly large-scale questionnaire survey, administered to graduates and instructors. The main purpose of the study was to determine perceptions of the foreign language needs of Iranian MA students - Specifically those majoring in biology, psychology, physical training, accounting and west philosophy - of various stakeholders including students, subject-specific instructors, and English instructors; besides, the study investigated the main reason of low language proficiency in Iranian students and sought for some possible recommendations to solve the problem.

\subsection{Instruments}

Three instruments were used in the study: (1) interviews, (2) needs analysis questionnaires, and, (3) texts. At the beginning of the study, interviews were conducted with MA students of almost all majors in order to learn that the students of which majors were in more desperate need of English. The result of this preliminary interview revealed that in almost all majors, the references were in English, however in some of the majors, because of the nature of their disciplines, the students declared being in desperate need of English; for example biology needs more works of translation when compared with mathematics which is a highly logical discipline. Students who were majoring in mathematics could solve their problems in English more easily because their books contained more formulas and 
they could figure out the problems through the related formula even if they didn't get the point in English. After consulting with the students, the above mentioned majors were selected. Another phase of the study also included some interviews with both students and instructors. A list of questions was prepared, regarding such issues as the student's conception of English language, the areas of language difficulty which they were experiencing, as well as the respondents' attitudes towards language instruction, methodology and content of the English course. During the interview, the instructors were asked in particular about what they considered as the main reason of weak language proficiency of MA students in Iranian universities.

Another instrument used in this study was two sets of needs analysis questionnaire: (1) MA students' questionnaire, (2) Special subject and English language instructors' questionnaire. (Refer to appendix A \& B). The needs analysis questionnaires were developed after interviewing students and instructors. The purpose of conducting the interviews was to identify the possible issues relating the English language needs of students. The students' questionnaire had two parts. The first part consisted of seven items which dealt with personal information such as name, age, sex, the department in which the students were studying, whether the specialized English course was offered in their major of study or not, who were teaching specialized English course at their college, and what the multiplication number of English course in their major of study in MA entrance exam was. The second part which consisted of twenty eight items sought to explore the opinions of students about the expressed language needs as well as the problems of MA students regarding English language. The students were required to express their opinions about each statement by marking the options on a five-point Likert scale. The aim of distributing questionnaire to special subject and English language instructors was to explore their opinions about the English language learning needs of MA students .The instructors' questionnaire comprised 18 items, (item 1-5) aimed to explore the instructors' perspectives on the required academic skills that put the students in desperate need of English. Items 6-10 questioned the exact problematic areas faced by the students while tacking with English texts. The last eight items sought to explore the opinions of instructors about the assumed roots of problems concerning English language at MA level as well as evaluating the policy of University Entrance Exam (Konkur) regarding its' critical role in making the students involved and inspired to promote their English before entering universities. The same rating scale used for the students was also used for the instructors. The third instrument was specialized texts to be read by some of the students (after the interview) in order to diagnose the main area of difficulty faced by MA students of which they themselves were unaware. (Refer to appendix $\mathrm{C}$ for a full copy of texts)

\subsection{Participants}

A total of eighty students from five MA majors studying at university of Isfahan participated in the study. The participants of biology, accounting and west philosophy were twenty students in each major, making a total of sixty participants, and ten students in each major of psychology and physical training, making a total of twenty participants. In addition to these eighty MA students, twenty - five subject-specific instructors as well as seven English instructors took part in the study. The distribution of participants who took part in the study is illustrated in Table 1.

\section{Data Aollection and Analysis}

The required data for the study were collected over the spring semester of 2010 as described below. Once the first drafts of the two sets of needs analysis' questionnaires were prepared, a pilot study was performed on 5 students and 2 instructors at university of Isfahan to elicit information concerning the content of the items, and clarity of instructions. After revising the questionnaire based on the pilot study, the final versions of the questionnaires were administered to the participants. The Cronbach alpha-coefficient was used to determine the questionnaires' reliability, which was 0.82 .

Subsequent to studying the answers in the questionnaire, the researcher came to understand the fact that students might have some misconceptions about English language; therefore she arranged some interviews with some of the students who filled out the questionnaire and asked about their conception of English language. The students were also shown a text in their field of study in order to be diagnosed by the researcher in which area of English language (grammar, vocabulary, compound sentences, discourse, translation, etc) they actually have problem. The researcher also arranged some interviews with special subject and English language instructors.

\subsection{The interviews}

At the beginning of the study, interviews were conducted with MA students of almost all majors in order to learn that the students of which majors were in more desperate need of English. The result of this preliminary interview revealed that in almost all majors, the references were in English, however in some of the majors, because of the nature of their disciplines, the students themselves declared to be in desperate need of English. After consulting with the students, the five majors of biology, psychology, physical training, accounting and west philosophy were 
selected for the study.

Furthermore, in another phase of the study the researcher conducted and tape-recorded interviews with both MA students and instructors. A list of questions was prepared regarding such issues as the areas of language difficulty which they were experiencing, the student's conception of English language, as well as the respondents' attitudes towards language instruction, methodology and content of the English course. During the interview the instructors as well as the students were asked in particular about what they considered as the main reason of weak English language proficiency of MA students in Iran universities.

The responses provided by the interviewees were recorded and then transcribed by the researcher. The following section will summarize the interviewee's perception from three different perspectives: the students' perspective, subject-specific instructors' and English instructors' perspective.

\subsubsection{The Students' Perspective}

Most of the students (about 90\%) who took part in the interview contended that they needed to develop their skills in English language. They perceived their reading ability was insufficient to meet the challenge of the large amount of reading materials expected of them in their specialized courses. They said that they needed to read professional articles and make presentation in their classes; more to the point they complained that it is really demanding for them to translate the texts abounded with a myriad of long complicated sentences. Quite astonishingly, some of the students confessed that they have to give their texts to be translated by the students who were majoring in English. Even the students of some majors like biology and physical training expressed their dissatisfaction with the lack of a specialized English course, maintaining that they were in desperate need of English. In the meantime they stated that that they just like any other majors were in desperate need of English and demanded for at least a 2-credit specialized English course.

When asked about the language instruction, methodology and content of the English course, most of the students (76\%) complained about the methodology of the professors who were teaching Specialized English courses. Neither were they content with the content presented for the Specialized English course. They alleged that ESP instructors give them a pamphlet or a collection of articles in their field of study and wants them to read and translate the texts, and then the instructor wants the students to read their translations or tell their comprehension of the text. If there is something wrong with the students' translation, the instructor will correct the mistakes made by the students without explaining the reason or presenting any strategy to them. Majority of the students $(87 \%)$ believed that they are not taught the strategy of translating long complicated sentences.

The students were also questioned about the factors they considered as the main reason of their low English proficiency at MA level. In this regard, most of them (about 68\%) believed that this problem should have been solved in preceding levels when they were going through ESP text books before graduation, maintaining that the materials which were used in the ESP courses focused only on reading comprehension and translation. They were actually distant from their needs. Although ESP textbooks contained a selection of grammatical structures and terminologies related to their field of study, the emphasis was still at practicing those items at the sentence level. The students commented that they memorized many vocabularies, prefixes and suffixes in their English courses, but after the examination was over they were unable to recall them while reading any other specialized texts.

The students were also asked about their perception of English language. Almost all the students (93\%) were of the opinion that English is just knowledge of vocabulary and grammar. They thought that if they had enough knowledge of vocabulary and grammar, all their problems would have been solved. Needless to say, this answer was predicted by the researcher to be heard by the students. To be sure about the misunderstanding of students regarding their conception of English language, the researcher examined the participants of the interview by presenting some technical texts (each student in her/his own major of study).The analysis of the texts and the result gained throughout this procedure will be discussed in the next sections. (The analysis of texts)

\subsubsection{The Subject-specific instructors' Perspective}

During the interview, subject-specific instructors were asked about what they considered as the main reason of low English language proficiency of MA students in Iran universities. In order to elicit exact responses related to the question exposed, preferably those subject-specific instructors were elected to choose for the interview that had the experience of teaching Specialized English courses. These instructors who were quite aware of the students' problems indicated that teaching of the skills such as listening, speaking and writing have been totally neglected in the Educational system of Iran emphasizing that learning English calls for experience and cannot be solved just by working on English at MA level. Even most of the Subject-specific instructors (68\%) were dissatisfied with the low reading ability of MA students and emphasized that they have no other alternative but to translate specialized 
English texts which the students were to study in the ESP classes.

Additionally, the respondents stated that the main reason of low language proficiency of MA students should not be just attributed to the instruction before graduation. They believed that while reading skill and translation have been always emphasized in the ESP courses during Bachelor of Arts (BA) period, MA students are still panicked by the large amount of reading materials expected of them in their special courses. Subject-specific instructors mentioned that MA students should learn the organization of articles and texts; they are expected to know how to read, summarize, analyze and interpret a piece of research done in their field of study. Subject-specific instructors were dissatisfied with the students' poor writing ability at MA level, confessing that students lack the ability to use linguistic forms and the academic register appropriately. Almost all of the instructors (96\%) believed that the main reason of low English language proficiency of MA students stems from the poor instruction presented to students during 12 years of study in Iran schools. They all complained about Iran's poor educational system which is not able to train bilingual students like many countries all over the world. Consequently they believed in the necessity of change in the students' English education.

\subsubsection{The English instructors' Perspective}

English instructors were also questioned about the factors that they deemed as the main reason of low English language proficiency of MA students majoring in non-English disciplines. All the instructors had the same opinion as subject-specific instructors believing that the main reason of low language proficiency of MA students is caused by the poor instruction presented to students during 12 years of study in Iran schools. They all complained about the poor educational system of Iran schools which are unable to train students with high English language proficiency similar to many countries all over the world. English instructors believed in the necessity of change in the students' English education. Not only were they dissatisfied with the Grammar Translation Method (GTM) method of instruction in Iran schools but also they were opposed to the kind of syllabus and methodology of ESP instructors both at BA and MA level. English instructors stated that learning English demands a long-term exposure to the language and can not be solved just by working on English at BA or MA level, maintaining that students should be exposed to English language during the 12 years of education at schools. They also objected at the methodology of teachers, believing that Iran educational system is still based on Grammar Translation Method (GTM) and it lacks the emphasis on the most important element of language learning i.e. listening skill. They stressed that another important skill that MA students lack is writing, suggesting that students should be taught how to write academic articles and texts. Furthermore, they seriously denied subject-specific instructors' teaching of ESP courses, stating that there is no doubt in the knowledge of subject-specific instructors but teaching English needs its own methodology what most of the subject-specific instructors lack. Subject-specific instructors just correct the students' errors without teaching them how to cope with other texts independently, that's why their problems are seemingly solved at classrooms but students are unable to comprehend and translate other academic texts by their own. English instructors highlighted that the problem of MA students is beyond the knowledge of vocabulary and grammar that can be solved by technical texts; it is rather with general English such as the organization of texts and the parts of speech.

As a solution English instructors suggested a cooperative teaching of ESP courses, asserting that content specialists or teachers are experts in their own field of study; however, they may not be proficient enough to tackle the content texts in the target language that is English, therefore the ESP practitioner has to collaborate and co-operate with the content department in order to increase his/her knowledge regarding the specialist content which he/she has to teach. ESP practitioners have to consult and contact the content department to find out what the objective and subjective needs are and then based on the results of the needs analysis design course materials which would fulfill the students' needs.

\subsection{The texts}

A qualitative analysis of the data provided further evidence in support of the misperception of MA students regarding English language. During the interview, the students were asked about their perception of English language. Almost all the students (93\%) were of the opinion that English is just knowledge of vocabulary and grammar. They thought that if they had enough knowledge of vocabulary and grammar, all their problems would have been solved.

To understand the main areas of difficulty faced by MA students, the researcher tested the students through some technical texts. (See the extract of texts in the appendix). The students were asked to read the texts (each student in her own major) and highlight the parts which they were unable to translate or even comprehend.

\subsection{The questionnaires}

For every question of the questionnaires, a bar graph, a cross-tabulation chart, and a chi-square test result table was 
presented. The bar graph depicted the distribution of the answers by the whole population of the participants, in three separate clusters, on each intended question. The cross -tabulation charts presented detailed information about the break down of computations including expected count, within group percentage, within question percentage, and total for the distribution of answers for each and every question on the questionnaires.

\section{The Findings}

The first eighteen questions in all the questionnaires was similar, therefore the responses of participants in the question (1-18) were compared and analyzed through chi-square test.

The chi-square test result for the first five questions is as the following; Q1:The chi-square test results with a 7.645 value and an associated significance level of 0.265 , Q2: The chi-square test results with a 17.277 value and an associated significance level of 0.027 , Q3: The chi-square test results with a 18.867 value and an associated significance level of $0.016, \mathrm{Q} 4$ : The chi-square test results with a 32.897 value and an associated significance level of .000, and Q5: The chi-square test results with a 13.510 value and an associated significance level of 0.095 showed that for some of the items, students had the same opinion and for some others they had different ideas.

Again for Q6:The chi-square test results with a 43.856 value and an associated significance level of .000, Q7: The chi-square test results with a 22.364 value and an associated significance level of 0.004, Q8:The chi-square test results with a 30.768 value and an associated significance level of .000, Q9: The chi-square test results with a 12.225 value and an associated significance level of $0.141, \mathrm{Q} 10$ : The chi-square test results with a 27.072 value and an associated significance level of 0.001, Q11:The chi-square test results with a 12.832 value and an associated significance level of $0.118, \mathrm{Q} 12$ :The chi-square test results with a 30.143 value and an associated significance level of .000, Q13: The chi-square test results with a 40.102 value and an associated significance level of .000, Q14: The chi-square test results with a 21.402 value and an associated significance level of 0.006 ,

Q15: The chi-square test results with a 27.829 value and an associated significance level of 0.001, Q16: The chi-square test results with a 11.649 value and an associated significance level of $0.168, \mathrm{Q} 17$ : The chi-square test results with a 6.765 value and an associated significance level of 0.562 , and Q18: The chi-square test results with a 25.741 value and an associated significance level of 0.001 indicated that for some of the items, students had the same opinion and for some others they expressed different viewpoints.

Yet, the MA student's questionnaire had ten more additional items. Items 19-28 which were included only in the MA student's questionnaire are analyzed as the following. Tables 2 and 3 illustrate the distribution of students' answers to questions 19-28.

\section{Summary and Conclusion}

As it is illustrated in the following extracts, some of the problematic areas faced by the students are boldfaced. The findings indicate that students' knowledge of core vocabulary, semi technical and technical vocabulary was satisfactory; however most of the students had problems with the comprehension of complicated long sentences. There were some parts in the articles that the students were unable to determine the true reference of preposition. In addition, some of the students didn't have a true knowledge of parts of speech in English language; they could not find the subject of the sentence or they were unable to distinguish between the superlative or comparative adjectives. It was understood that when -ed or -ing is added to a word, the students were unable to understand the change in the structure of the sentence, hence they could not understand the change in the meaning.

For the most part, students' problem was diagnosed in the general English rather than technical English. The students had difficulty in the comprehension of organization of the texts. They could not understand the relation of one sentence to the previous or next sentence. The students' problem was mostly related to the structure and grammar of English, such as the omission of relative pronoun along with the TO BE verbs.

A needs analysis study was carried out in the University of Isfahan with the aim of investigating graduate students' foreign language learning needs, wants and lacks. The assessment of learners' needs was performed with the help of various stakeholders including MA students who were majoring in biology, psychology, physical training, accounting and west philosophy, EFL and subject-specific instructors.

The first research question explored the views and perceptions of the students as well as instructors concerning the ESP needs of students. The findings of the study supported the view that MA students, 'greatly' need to increase their general proficiency in English. Even after studying the answers in the questionnaires, the researcher came to understand the fact that students might have some misconceptions about English language; therefore she arranged some interviews with some of the students who filled out the questionnaire and asked about their conception of English language. The students were also shown a text in their field of study in order to be diagnosed by the researcher in which area of English language (grammar, vocabulary, compound sentences, discourse, translation, etc) 
they actually had problem. Quite amazingly, the findings of interview along with the text analysis revealed that the students' knowledge of core vocabulary, semi - technical and technical vocabulary was satisfactory; however most of the students had problems with the comprehension of complicated long sentences. There were some parts in the articles that the students were unable to determine the true reference of preposition. In addition, some of the students didn't have a true knowledge of parts of speech in English language; they couldn't find the subject of the sentence or they couldn't distinguish between the superlative or comparative adjectives. It was understood that when -ed or -ing is added to a word, the students were unable to understand the change in the structure of the sentence, hence couldn't understand the change in the meaning English. For the most part, students' problem was diagnosed in the general English rather than technical English. The students had difficulty in the comprehension of organization of the texts; they couldn't understand the relation of one sentence to the previous or next sentence.

This indicates that in spite of the fact that the students take a general English course before their subject-specific English course; their level of general English proficiency (GEP) is low. This is in line with what has also been echoed in the literature on EFL/ESP in Iranian settings (Alavi and Tahririan, 1996), (Atai, 2000), (Tahririan, 1987), (Tahririan, 1990) and (Mazdayasna, 2008). Students also perceived that English instructors lack sufficient expertise and background knowledge required for teaching specialized English courses. Nevertheless, all subject specific instructors indicated that EFL instructors should teach ESP courses. Additionally, half of the subject-specific instructors were of the opinion that EFL instructors must have sufficient knowledge of the specialized vocabulary, while the rest perceived that EFL instructors should have knowledge of specialized vocabulary as well as general vocabulary. This confirms the recommendation of Atai $(2002$, p.13) that "EAP instructors reconsider their roles in struggling with EAP contexts and to widen their repertoires of language teaching strategies". It does not, of course, in any way address the impracticality of these expectations.

The second research question sought information about the main reason of the student's low language proficiency at MA level as well as some possible recommendations to solve the problem. In order to answer the second research question, some interviews along with text analysis were done. In addition, items 17 and 18 also questioned the policy of Konkur exam as a possible solution to the aforementioned problems.

In this regard, most of students believed that the problem of low language proficiency should have been solved at BA level when they were going through ESP text books, maintaining that the materials which were used in the ESP courses focused only on reading comprehension and translation. They were actually distant from their needs. Although the textbooks contained a selection of grammatical structures and terminologies related to their field of study, the emphasis was still at practicing those items at the sentence level. The students commented that they memorized many vocabularies, prefixes and suffixes in their English courses, but after the examination was over they were unable to recall them while reading any other specialized texts.

Additionally, the respondents stated that the main reason of low language proficiency of MA students should not be just rooted out in the instruction at BA level. They believed that in spite of the fact that reading skill and translation has been always emphasized in the ESP courses during BA level, MA students are still panicked by the large amount of reading expected of them in their special courses. These instructors mentioned that MA students should learn the organization of articles and texts; they are expected to know how to read, summarize, analyze and interpret a piece of research done in their field of study. The ESP instructors also felt the need for the students to practice how to write their own academic articles in English. They were dissatisfied with the students' poor writing ability at MA level, confessing that students lack the ability to use linguistic forms and the academic register appropriately. Almost all the English instructors had the same opinion as subject-specific instructors believing that the main reason of weak language proficiency of MA students is caused by the poor instruction presented to the student during 12 years of study in Iran schools. They all complained about the poor educational system of Iran schools which are unable to train students with high English language proficiency similar to many countries all over the world. English instructors believed in the necessity of change in the students' English education. Not only were they dissatisfied with the GTM method of instruction in Iran schools but also they were opposed to the kind of syllabus and methodology of ESP instructors both at BA and MA level. English instructors stated that learning English demands a long -term exposure to the language and can not be solved just by working on English at BA or MA level, maintaining that students should be exposed to English language during the 12 years of education at schools. English instructors also objected at the methodology of teachers, believing that Iran educational system is still based on Grammar Translation Method (GTM) and it lack the emphasis on the most important part of language learning i.e. listening skill. They stressed that another important skill that MA students lack is writing, suggesting that students should be taught how to write academic articles and texts. Furthermore, they seriously denied subject-specific instructors' teaching of ESP courses, stating that there is no doubt in the knowledge of subject-specific instructors but teaching English needs its own methodology, what most of the subject-specific instructors lack. Subject-specific 
instructors just correct the students' errors without teaching them how to cope with other texts independently, that's why their problems are seemingly solved at the classroom but the students are unable to comprehend and translate other academic texts independently. English instructors highlighted that the problem of MA students is beyond the knowledge of vocabulary and grammar that can be solved by technical texts; it is rather with general English such as the organization of texts and the parts of speech.

Giving more weight to English course in the MA entrance exam was suggested by the researcher as one possible solution to the problem. The majority of participants believed that the idea of increasing the multiplication number of English course in the MA entrance exam would initiate enough motivation for the students to improve their language proficiency.

A cooperative teaching of ESP courses is suggested as another solution, asserting that content specialists or teachers are experts in their own field and in L1 in our case Persian; however, they may not be proficient enough to tackle the content texts in the target language that is English, therefore the ESP practitioner has to collaborate and co-operate with the content department in order to increase his/her knowledge regarding the specialist content which he/she has to teach. ESP practitioners have to consult and contact the content department to find out what the objective and subjective needs are and then based on the results of the needs analysis design course materials which would fulfill the students' needs.

\section{References}

Atai, M. R. (2000). ESP revisited: a reappraisal study of discipline-based EAP programs in Iran. Unpublished Ph.D. dissertation. University of Esfahan, Esfahan, Iran.

Atai, M. R. (2002a). Iranian EAP programs in practice: A study of key methodological aspects. Sheikhbahaee ELT Journal, 1(2), 1-15

Atai, M. R. (2002b). ESP methodology revisited: A genre-based reading comprehension course for students of dentistry. Indian Journal of Applied Linguistics, 28(1), 77-90

Dudley-Evans, T. Shettlesworth, C. C., \& Philips, M. K. (1976). The ESP materials of the University of Azarbayejan, Tabriz, Iran. In J. Richards (Ed.), Teaching English for science and technology, SEAMEO, Regional English Language Center. Singapore: Sangapore University Press. pp. 163-167

Eslami, R. A. (2005). A no man's land area of activity: Investigating ESP courses administered in Iranian Universities. Proceedings of the First National ESP/EAP Conference. The center for Research and Development in Humanities of SAMT, Tehran, Iran.

Fakharzadeh, M. (2000). Analyzing discoursal and formal needs of students of Psychology and sociology. Unpublished MA thesis. University of Esfahan, Esfahan, Iran.

Mazdayasna, G. (2008). Developing a profile of the ESP needs for the students of medical and midwifery in Iran. Unpublished Ph.D. dissertation. University of Esfahan, Esfahan, Iran.

S. Alavi, \& M. H. Tahririan. (1996). EFL learners' proficiency and their performance on GPE and ESP collocations. Indian Journal of Applied Linguistics, 22(2)

Tahririan, M. H. (1987). ESP, Yes, But for What Learners? IAPE, Esfahan, 3

Tahririan, M. H. (1990). A summative evaluation of teaching English in Iranian universities. Research Bulletin of Esfahan University, 6 (2)

Yarmohammadi, L. (2005). ESP in Iran from language planning perspective. Proceedings of the First National ESP/EAP Conference, 2, 2-20. The Center for Research and Development in Humanities of SAMT. Tehran.

Table 1. Distribution of participants who took part in the questionnaire survey

\begin{tabular}{|l|c|c|c|}
\hline Participants & MA student & subject-specific instructors & English instructors \\
\hline Numbers & 80 & 25 & 7 \\
\hline
\end{tabular}


Table 2. Cross tabulation of merged cells for Q19-24

\begin{tabular}{|c|l|c|c|c|c|}
\hline Item \# & Group & Agree $\%$ & No idea\% & Disagree $\%$ & Total count \\
\hline 19 & MA students & 65 & 21.3 & 13.8 & 80 \\
\hline 20 & MA students & 26 & 37 & 37 & 80 \\
\hline 21 & MA students & 50.7 & 24.1 & 25.3 & 80 \\
\hline 22 & MA students & 25 & 16.3 & 58.8 & 80 \\
\hline 23 & MA students & 52.6 & 19.2 & 28.2 & 80 \\
\hline 24 & MA students & 96.2 & 2.5 & 1.3 & 80 \\
\hline
\end{tabular}

Table 3. Cross tabulation of merged cells for Q25-28

\begin{tabular}{|c|l|c|c|c|c|}
\hline Item \# & Group & A little\% & Moderately\% & Greatly\% & Total count \\
\hline 25 & MA students & 33.4 & 51.3 & 15.4 & 80 \\
\hline 26 & MA students & 28.2 & 28.2 & 43.6 & 80 \\
\hline 27 & MA students & 23.1 & 53.8 & 23.1 & 80 \\
\hline 28 & MA students & 7.7 & 56.4 & 35.9 & 80 \\
\hline
\end{tabular}

